\title{
HOW TO SELECT POTENTIAL SPECIES FOR ECOLOGICAL RESTORATION OF RAIN FOREST - SOUTHERN BRAZIL
}

\author{
ADENESKY-FILHO, E. ${ }^{1 *}-$ MAÇANEIRO, J. P. ${ }^{2}-$ VITORINO, M. D. ${ }^{1}$ \\ ${ }^{1}$ Department of Forestry Engineering, Regional University of Blumenau \\ Box. 89030-000 Blumenau, Brazil \\ ${ }^{2}$ Department of Forestry Engineering, Federal University of Paraná \\ Box. 80210-170 Curitiba, Brazil \\ *Corresponding author \\ e-mail: eduardo_adenesky@yahoo.com.br \\ phone: +55-042-99948-2883 \\ (Received $27^{\text {th }}$ Jan 2017; accepted $19^{\text {th }}$ May 2017)
}

\begin{abstract}
Monitoring of natural regeneration can provide information on potential species for use in ecological restoration projects, as well as provide indications of the area resilience after degradation. In order to analyze variations of natural regeneration in two successional stages and to subsidize the indication of species for planting and enrichness, two abandoned pastures were sampled in Serra do Itajaí National Park (PNSI), Santa Catarina state, Southern Brazil. In the analysis of the main components, the plots differed according to the change in the quantitative variables of the species (Monte Carlo, $\mathrm{P} \leq 0.05$ ), and two groups were segregated: the first one constituted by the vegetation in the initial stage, and the second one, by intermediate stage vegetation. Twenty-one species were sampled and the intermediate stage showed the greatest richness $(\mathrm{n}=19)$. The pioneer species were predominant in both stages, especially Vernonanthura discolor, Piptocarpha regnellii and Myrsine coriacea. The results demonstrate that the initial stage does not have indicator species, because all species occur frequently in the intermediate stage. However, the intermediate stage was distinguished by the presence of eight indicator species, which are potentially recommended for reforestation and enrichment plantations of Montana Ombrophilous Dense Forest in the PNSI.
\end{abstract}

Keywords: successional stages, tree species, forest ecology, ecological groups and tropical forest

\section{Introduction}

Neotropical forests have a large fraction of the planet's biological diversity and comprise the most threatened biomes due to the conversion of areas with native vegetation to pasture and agricultural use (Scarano and Ceotto, 2015). From the environmental point of view, pastures are rarely sustainable for a long time, since their intensive use leads to environment degradation and, subsequently, to the abandonment of those areas (Dirzo and Raven, 2003). Among the main causes of pasture degradation is soil compaction which, due to the intense animal trampling, changes the physical and chemical properties of the soil, besides restricting water infiltration and the development of plant root systems (Albuquerque et al., 2001).

In degraded pastures, the natural regeneration process is influenced by the use and degradation history of the site and by the vegetative matrix inserted in the surroundings, being more active in places close to the forest fragments that provide propagules to the degraded area (Rodrigues and Gandolfi, 2007; Martins, 2013). In addition, the monitoring of such regenerating areas can provide relevant information regarding the species being initially established, and may serve as a basis for the selection of potential species to be used in restoration projects in different environments (Rodrigues et al., 
2009; Daronco et al., 2013; Marcuzzo et al., 2014), since the collection of matrix seeds in the surroundings of the area where the restoration will be carried out can increase the probability of reforestation success, in terms of survival and growing (Sebben, 2006), as well as guarantee the local genetic of plants and allow greater ecological adaptation plasticity to the local conditions (Palma and Laurence, 2015).

The pastures located inside the Conservation Units are considered excellent sites for the development of researches that evaluate aspects related to ecological succession, since in most cases these areas have a contingent of forest matrix in their surroundings and are propitious for the establishment of forest coverage. In this sense, the Serra do Itajaí National Park (PNSI) is an Integral Protection Conservation Unit created by decree on June 4, 2004. The PNSI has a total area of 57,374 ha, covers nine municipalities and conserves a significant portion of the Atlantic Forest in Santa Catarina state (ICMBIO, 2009), currently reduced by only $11.7 \%$ of its original coverage (Rezende et al., 2015). Several areas within the Serra do Itajaí National Park have been severely degraded by agriculture and cattle ranching due to intensive land use since 1953 , making a total of 1,453 hectares.

In this sense, considering the importance of vegetation studies in the orientation of ecological restoration projects, the present work aimed to analyze the variations in vegetation composition and structure in two successional phases to subsidize the indication of tree species for new reforestation and enrichness of abandoned pastures in Serra do Itajaí National Park, Santa Catarina, Southern Brazil.

\section{Materials and methods}

\section{Study area}

Asd Serra do Itajaí National Park (PNSI) has a total area of 57,374 ha, which ranges from 60 to $1,039 \mathrm{~m}$ high and is located in the Itajaí river basin, Santa Catarina state, Southern Brazil (Fig. 1). This Conservation Unit covers nine municipalities (Ascurra, Apiúna, Blumenau, Botuverá, Gaspar, Guabiruba, Indaial, Presidente Nereu and Vidal Ramos) and is located between $27^{\circ} 00$ 'and $27^{\circ} 17^{\prime} \mathrm{S}$ and $49^{\circ} 01$ 'and $49^{\circ} 21^{\prime} \mathrm{W}$. This work was developed in the area of Faxinal do Bepe, located inside the PNSI, at an altitude of about 400 to 800 meters and surrounded by vegetation belonging to the Montana Ombrophilous Dense Forest (ICMBIO, 2009).

The climate of the study area, according to Köppen's classification, is $\mathrm{Cfb}$ - moist mesothermal climate with mild summer (Alvares et al., 2013). The annual temperature average varies between 16 and $20^{\circ} \mathrm{C}$, the annual relative humidity average ranges between 82 and $84 \%$ and the total annual precipitation is between 1,500 and 1,700 mm, well distributed over the year (Pandolfo et al., 2002).

The geology of the region is formed by the Itajai Group, composed of metaconglomerate rocks, and by the Tabuleiro Complex, composed of granite-gneiss rocks (Aumond et al., 2014). In the study area, an association among six types of soil predominates: in corrugated land, the Yellow-Red Ultisol and Haplic Cambisol types, in strong undulating and mountainous soils, the Litholic Neosol and Rogosols kinds and, in flat areas characterized by alluvial plains, the Fluvic Neosol and Haplic Gleisol soil types (Santos et al., 2013).

The type of vegetation in the study area is constituted by the Montana Ombrophilous Dense Forest (IBGE, 2012) belonging to the Atlantic Forest domain. On the historical use of natural resources, between the years 1953 and 2004 much of the study area of 
forests was subjected to selective cutting, in addition to being harvested to make room for extensive areas of pasture and agriculture. Currently, the remaining vegetation is in early, middle and advanced stages of regeneration (Schorn and Maçaneiro, 2014).
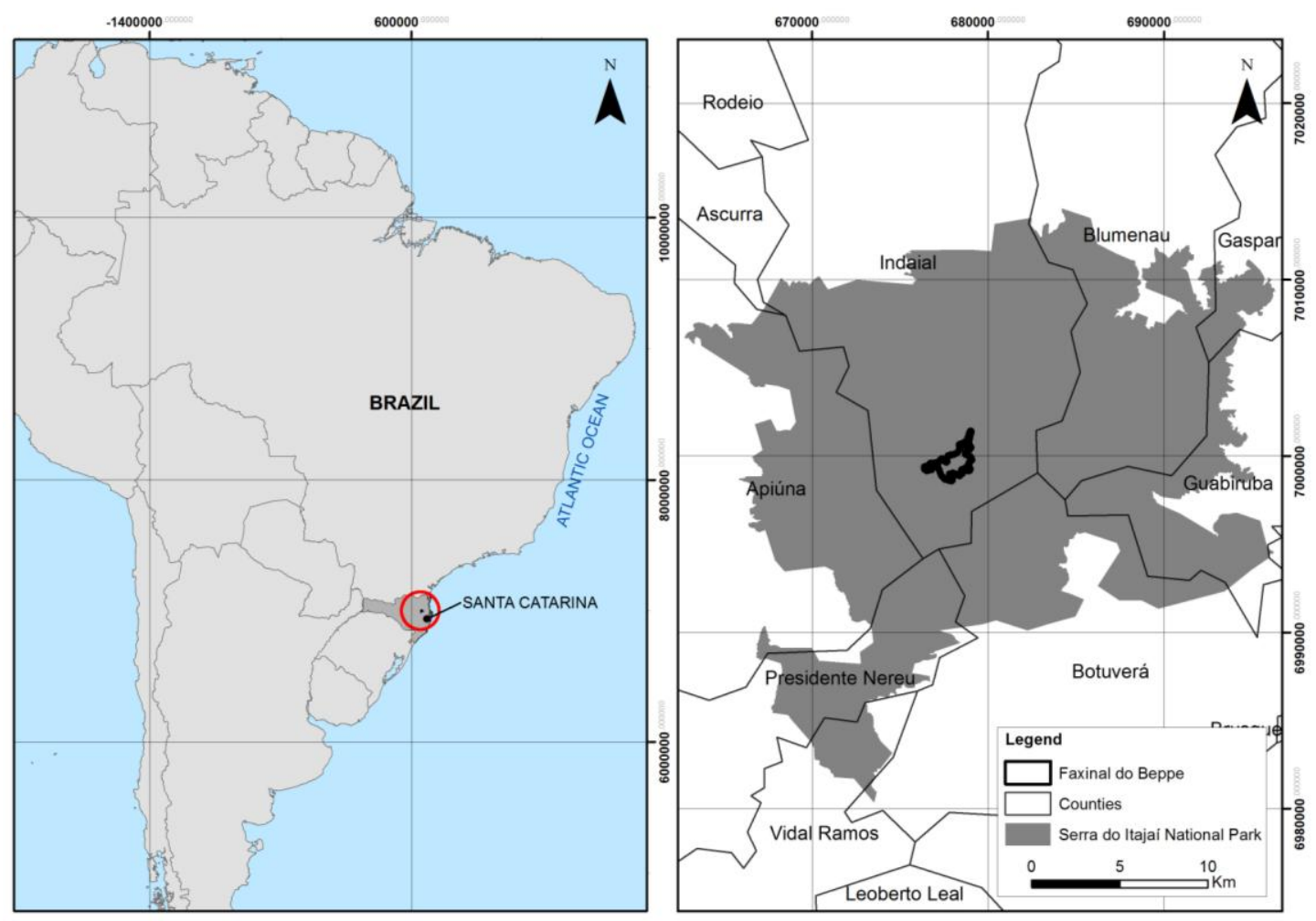

Figure 1. Map of the location of the National Park Serra do Itajai (gray area), and the locality of the Faxinal do Bepe (circled black), in Santa Catarina, Brazil

\section{Data collection and analysis}

For the vegetation sampling, the plots method (Moro and Martins, 2011) was used, in order to contemplate two distinct successional phases. In total, 40 plots of $10 \times 20 \mathrm{~m}$ $\left(200 \mathrm{~m}^{2}\right)$, totaling $8,000 \mathrm{~m}^{2}$ of sample area, were distributed as follows: initial regeneration phase $=20$ plots, and intermediate regeneration phase $=20$ plots, respectively (Fig. 2). In order to proceed to the survey of the regenerating stratum, all trees and shrubs with diameter at breast height $(\mathrm{DBH}) \geq 3,0 \mathrm{~cm}$ were sampled. Two subplots of $1 \times 1 \mathrm{~m}\left(1 \mathrm{~m}^{2}\right)$ were inserted into each part of the regenerating stratum, for the herbaceous stratum, characterized by plants with height greater than or equal to 20 $\mathrm{cm}$ and $\mathrm{DBH}<3,0 \mathrm{~cm}$.

The collected botanical material was deposited in the Herbarium Dr. Roberto Miguel Klein, from the Regional University of Blumenau (FURB), identified by comparison with other exsicatas, the digital photographs were published at Flora Digital (http://ufrgs.br/floradigital) and Herbário Virtual (http://reflora.jbrj.gov.br/) websites and also sent to FURB specialists. The classification system used was the Angiosperm Phylogeny Group IV (APG IV, 2016).

The richness of species in the successional stages was compared by means of rarefaction curves using the Mao Tau method (Colwell et al., 2011). This method was used based on the number of observed individuals. 


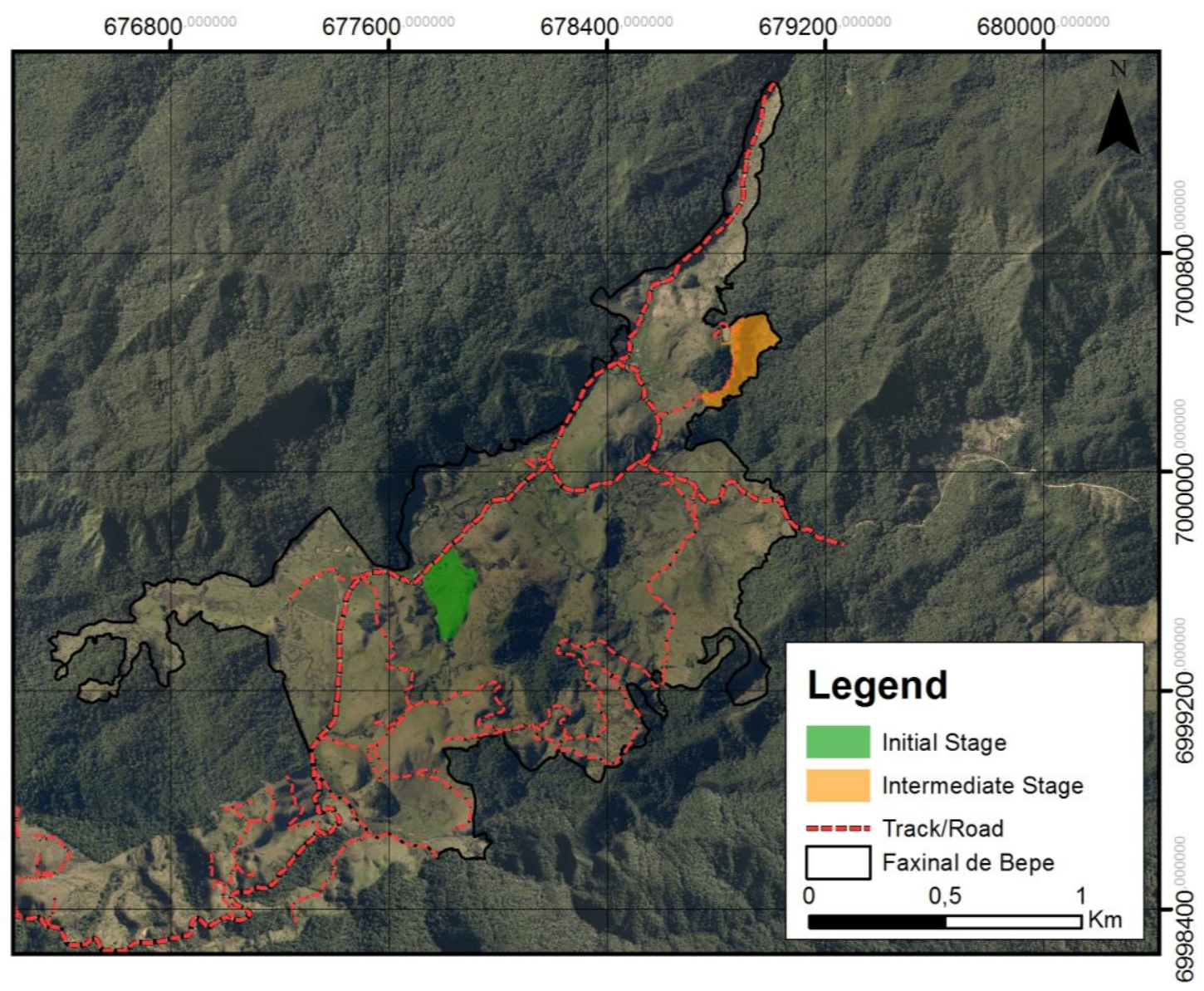

Figure 2. Map of the location of the inventoried areas, inside the National Park Serra do Itajai. Initial stage area (green) and intermediate stage (orange)

To describe the vegetation structure, the classical phytosociological parameters, i.e., density, dominance absolute and relative frequencies species were calculated for each successional phase (Moro and Martins, 2011). Then the species were classified per ecological group, adopting Swaine and Whitmore's (1988) methodology adapted by Oliveira-Filho (1994), in the following categories: pioneer (P), light demanding climax (CL) and shadow tolerant climax (CS).

The influence of the vegetation quantitative variables in the plots was analyzed through Principal Component Analysis - PCA (Legendre and Legendre, 2012). In order to identify and remove the collinear quantitative variables, a preliminary PCA was performed in PC-ORD 6.0 (McCune and Mefford, 2011), following Eisenlohr's (2014) recommendations. After this procedure, the quantitative variables that remained in the analysis were: regenerating stratum - multiple stems, number of trees, tree species, tree height, DBH (diameter at breast height) and basal area - and herbaceous stratum - herb species and herb height. Then, a new PCA was processed in order to synthesize the quantitative variables of the plots into ordering axes. This PCA will hereafter be referred to as the 'final PCA'. The significance of the ordering axes was verified by means of 999 Monte Carlo permutations (Legendre and Legendre, 2012).

In order to detect potential tree species for new plantings on abandoned pastures of the PNSI, the indicator species analysis was used and the indicator values for each 
species were obtained using Dufrene and Legendre's (1997) method. In this analysis, the basal area of the species in the successional phases was used, since after processing the final PCA, it was verified that the basal area was the structural variable more correlated with the vegetation data.

\section{Results and discussion}

Species richness increased as the succession progressed (Fig. 3). In the early-stage, the richness was estimated in ten species, considering the standardization of 166 individuals in the sample, while the intermediate stage presented 15 species. Although individuals do not approach the stabilization of rarefaction curves within each analyzed succession stage, there was a considerable increase in the number of species in accordance with the advance in the forest succession process. The increase of species richness as a function of succession time has already been verified by other studies (Schorn, 2005; Ruschel et al., 2009; Zanini et al., 2014; Garcia et al., 2016), in which the richness of tree species increases as the structural complexity of forests becomes higher and is related to longer ecological succession process. However, additional factors such as the availability of propagules close to the studied area also influence natural regeneration and, consequently, species richness (Martins, 2013). In the present study, differences in the time of regeneration increase the vegetation floristic-structural complexity and create conditions for changes in the composition and abundance of species, as well as for the presence of a forest structure in full recovery in the environment.

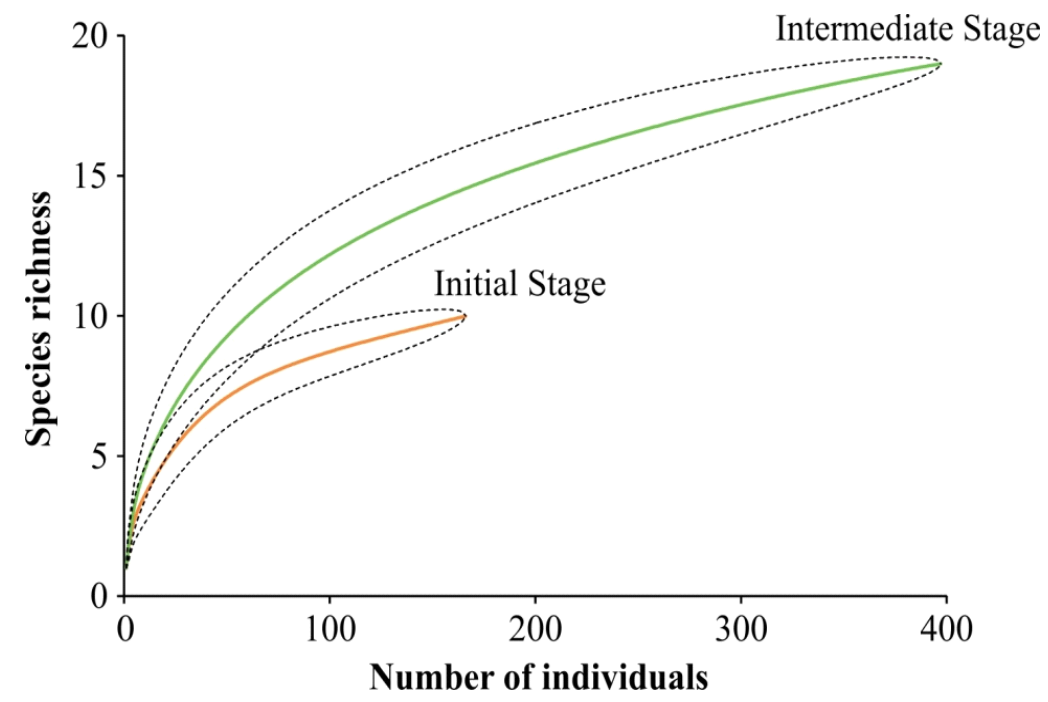

Figure 3. Rarefaction curves obtained by the Mao Tau method, with their respective confidence intervals ( $\pm 95 \%$ CI), for species in two successional stages in the Serra do Itajai National Park, Santa Catarina state, Southern Brazil

In the Principal Component Analysis (PCA final), the plots differed according to the variation in the quantitative variables of the species in the successional phases. The first two ordering axes explained $68.7 \%$ of the data variance (axis $1=51.3 \%$, axis $2=$ $17.4 \%)$ and presented statistical significance by the Monte Carlo test $(\mathrm{P} \leq 0.05)$. The quantitative variables that correlated with axis 1 were $\mathrm{DBH}$, basal area, number of trees, 
tree height, tree species and herb species, and with axis 2, they were multiple stems and herb heights (Fig. 4). These axes discriminated a strong structural gradient among the analyzed variables and segregated two groups of plots: the first one constituted by the vegetation in the initial stage of regeneration, whose quantitative variables are not very expressive, and the second one constituted by the vegetation in the intermediate stage of regeneration, in which quantitative variables are quite expressive.

The results show that the structural variables of the vegetation vary according to the successional stage. Thus, these environments must be treated differently. The differences among the analyzed successional phases are mainly related to the basal area, $\mathrm{DBH}$, number of trees, tree heights and multiple stems of tree species, as well as herb species for herbaceous species, which were the main structural variables that segregated the analyzed plots. In subtropical forests, studies have shown that the progression of the succession process reflects changes in vegetation coverage, with a considerable increase in its structural complexity and species richness (Garcia et al., 2016). Some structural variables (eg, basal area, DBH, number of trees and tree heights) are more expressive in intermediate and advanced forests stages, which demonstrates their greater development and longer succession. On the other hand, in early-stage the physiognomy of vegetation is generally more open and with arboreal individuals distributed sparsely or in spots. Under these conditions, structural variables such as multiple stems and herb heights are also important descriptors of vegetation structure. For example, early-stage forests present intense solar radiation on the soil, which contributes considerably to the growth of herbaceous plants (Reznick et al., 2002; Blute, 2016) and to the maintenance of grasses, until the closure of tree crowns is able to interfere substantially in the incident radiation, since in these areas the trees tend to emit a greater number of lateral branches due to the greater availability of space for capturing solar radiation and for foliar production (Hallé, 2010).

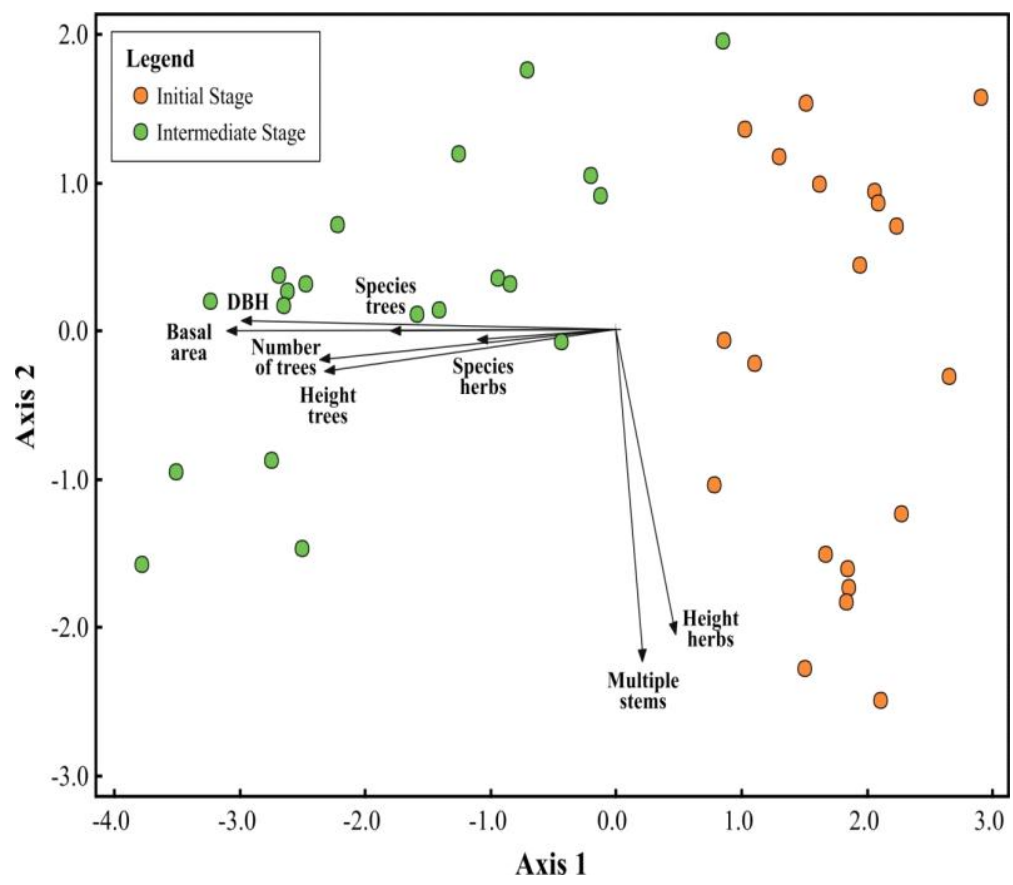

Figure 4. Ordering diagram produced by Principal Component Analysis (PCA final), based on the quantitative variables of the species in 40 two-phase successional plots in the Serra do Itajai National Park, Santa Catarina state, Southern Brazil 
In addition, so that these analyzed variables are actually expressed in the restoration process community, it is of fundamental importance that the species are representative of the local population, which, according to Brancalion et al. (2009), avoids future problems in the establishment of seedlings and the ecological expression of the species with the plant community.

In this way, the analyzed parameters, besides providing a structural information framework of the fragments, also provide references on the ecological characteristics, such as the initial structuring of a population, covering the area with arboreal and herbaceous individuals, and a later intermediate physiognomy with greater intensity and complexity, favoring the coverage (crown density and dominance), giving rise to new fauna attracting sites. This directional complexity of plant succession allows us to predict the possible inferences necessary to support the restoration trajectory, such as the need to increase species density and richness from early to advanced stage, as well as to enrich degraded areas that need specific functional groups to boost fragile natural regeneration.

The successional phases analyzed are predominantly characterized by pioneer species (initial stage $=80.0 \%$ and intermediate stage $=73.7 \%$ ). In the initial stage, Piptocarpha regnellii (Sch.Bip.) Baker (IVI = 119.5\%) and Vernonanthura discolor (Spreng.) H.Rob. $(\mathrm{IVI}=106.1 \%)$ were the highest values of importance (Table 1) and, at the intermediate stage, the most important species were Vernonanthura discolor $(\mathrm{IVI}=96.7 \%)$ and Piptocarpha regnellii (IVI $=75.7 \%$ ), characterizing the vegetation physiognomy. Eight indicative species were identified in the successional stages analyzed and those with significant values (Monte Carlo, $\mathrm{P} \leq 0.05$ ) were Baccharis dracunculifolia DC., Clethra scabra Pers., Myrsine coriacea (Sw.) R.Br. ex Roem. \& Schult., Piptocarpha angustifolia Dusén ex Malme, Piptocarpha axillaris (Less.) Baker, Piptocarpha regnellii, Tibouchina sellowiana Cogn. and Vernonanthura discolor (Table 2).

In relation to the most important species, Vernonanthura discolor, Piptocarpha regnellii and Myrsine coriacea are heliophilous pioneers typical of open environments or forest edges, being able to form dense populations clusters in newly abandoned pastures and in the process of natural regeneration (Klein, 1980; Schorn and Maçaneiro, 2014). In general, in the subtropical forests of southern Brazil, the greatest number of pioneer species is found predominantly in young forests, characterized by early-stage vegetation (Schorn and Galvão, 2009; Simmski 2009; Lingner et al., 2013). As the succession process progresses, the pioneer species modify the local environmental conditions, making the environment favorable for the colonization of new demanding species (for example, light demanding climax and shadow tolerant climax), which was verified by the double increase in the number of light-demanding climax species (initial stage $=10.0 \%$ and intermediate stage $=21.1 \%$ ), especially Annona emarginata (Schltdl.) H. Rainer, Myrcia splendens (Sw.) DC., Ocotea puberula (Rich.) Nees and Styrax leprosus Hook. \& Arn., which were unique to the intermediate stage.

For the initial stage, the species that presented the highest values of importance are promising for the use in restoration plantations, such as the enrichness of recently abandoned pastures in the phytoecological unit Montana Ombrophilous Dense Forest, since they are common in these environments because they are more adapted to open areas or forest edges. Regarding the density of tree species per hectare, it is recommended to respect the approximate number of individuals sampled in the areas undergoing initial regeneration. As an example, in this study the value was 418 individuals per hectare (Table 3). 
On the other hand, in areas with an intermediate stage, the vegetation is in an advanced process of succession, presenting greater floristic-structural complexity and more favorable environmental conditions for the entry of new demanding species (Klein, 1980; Schorn and Galvão, 2009). In these environments, it is recommended the enrichness planting, taking into account the species of the early and intermediate stages, following the proportion of the number of trees by species according to the difference between the density of individuals sampled in initial and intermediate stage areas. In the present study, there were approximately 602 individuals per hectare (Table 3). In addition, it is recommended to use the indicator species detected in the present study (Table 2), since the local and typical environmental conditions of late successional stages are adapted.

Table 1. Relation of species sampled in two successional stages in Serra do Itajai National Park, Santa Catarina state, Southern Brazil. $D A=$ absolute density $\left(\right.$ ind. $\left.h a^{-1}\right) ; D R=$ relative density (\%); $F A=$ absolute frequency (\%); $F R=$ relative frequency (\%); DoA = absolute dominance $\left(\mathrm{m}^{2} . h a^{-1}\right) ; D o R=$ relative dominance $(\%) ; I V I=$ importance value index (\%); EG $=$ ecological groups, $P=$ pioneer species, $C L=$ light-demanding climax, $C S=$ shadetolerant climax.

\begin{tabular}{|c|c|c|c|c|c|c|c|c|}
\hline Sucessional Stages / Species & DA & DR & FA & FR & DoA & DoR & IVI & EG \\
\hline \multicolumn{9}{|l|}{ Initial Stage } \\
\hline Piptocarpha regnellii (Sch.Bip.) Baker & 180 & 43.1 & 80.0 & 29.6 & 0.61 & 46.6 & 119.3 & $\mathrm{P}$ \\
\hline $\begin{array}{l}\text { Vernonanthura discolor (Spreng.) } \\
\text { H.Rob. }\end{array}$ & 160 & 38.3 & 85.0 & 31.5 & 0.47 & 35.9 & 105.6 & $\mathrm{P}$ \\
\hline Vernonanthura puberula (Less.) H.Rob. & 15 & 3.59 & 25.0 & 9.3 & 0.06 & 4.6 & 17.4 & $\mathrm{P}$ \\
\hline $\begin{array}{l}\text { Myrsine coriacea (Sw.) R.Br. ex Roem. } \\
\text { \& Schult. }\end{array}$ & 18 & 4.31 & 20.0 & 7.4 & 0.04 & 3.1 & 14.8 & $\mathrm{P}$ \\
\hline Piptocarpha axillaris (Less.) Baker & 15 & 3.59 & 20.0 & 7.4 & 0.05 & 3.8 & 14.8 & $P$ \\
\hline $\begin{array}{l}\text { Piptocarpha angustifolia Dusén ex } \\
\text { Malme }\end{array}$ & 13 & 3.11 & 10.0 & 3.7 & 0.04 & 3.1 & 9.9 & $\mathrm{P}$ \\
\hline Baccharis semiserrata DC. & 8 & 1.91 & 15.0 & 5.6 & 0.01 & 0.8 & 8.2 & $\mathrm{P}$ \\
\hline Zanthoxylum rhoifolium Lam. & 3 & 0.72 & 5.0 & 1.9 & 0.02 & 1.5 & 4.1 & $\mathrm{CL}$ \\
\hline Ilex paraguariensis A.St.-Hil. & 3 & 0.72 & 5.0 & 1.9 & 0.01 & 0.4 & 3.0 & $\mathrm{CS}$ \\
\hline Solanum mauritianum Scop. & 3 & 0.72 & 5.0 & 1.9 & 0.01 & 0.4 & 3.0 & $\mathrm{P}$ \\
\hline Total & 418 & 100.0 & 270.0 & 100.0 & 1.31 & 100.0 & 300.0 & - \\
\hline \multicolumn{9}{|l|}{ Intermediate Stage } \\
\hline $\begin{array}{l}\text { Vernonanthura discolor (Spreng.) } \\
\text { H.Rob. }\end{array}$ & 353 & 35.3 & 85.0 & 18.5 & 24.47 & 42.7 & 96.5 & $\mathrm{P}$ \\
\hline Piptocarpha regnellii (Sch.Bip.) Baker & 323 & 32.3 & 75.0 & 16.3 & 15.44 & 27.0 & 75.6 & $\mathrm{P}$ \\
\hline $\begin{array}{l}\text { Myrsine coriacea (Sw.) R.Br. ex Roem. } \\
\text { \& Schult. }\end{array}$ & 113 & 11.3 & 80.0 & 17.4 & 5.55 & 9.7 & 38.4 & $\mathrm{P}$ \\
\hline Piptocarpha axillaris (Less.) Baker & 58 & 5.81 & 30.0 & 6.5 & 2.53 & 4.4 & 16.7 & $\mathrm{P}$ \\
\hline $\begin{array}{l}\text { Piptocarpha angustifolia Dusén ex } \\
\text { Malme }\end{array}$ & 30 & 3.0 & 35.0 & 7.6 & 3.36 & 5.9 & 16.5 & $\mathrm{P}$ \\
\hline Tibouchina sellowiana Cogn. & 28 & 2.8 & 30.0 & 6.5 & 0.98 & 1.7 & 11.0 & $\mathrm{P}$ \\
\hline Baccharis dracunculifolia DC. & 13 & 1.3 & 25.0 & 5.4 & 0.78 & 1.4 & 8.1 & $\mathrm{P}$ \\
\hline Clethra scabra Pers. & 18 & 1.8 & 25.0 & 5.4 & 0.40 & 0.7 & 7.9 & $\mathrm{P}$ \\
\hline Tibouchina pilosa Cogn. & 15 & 1.5 & 5.0 & 1.1 & 1.60 & 2.8 & 5.4 & $\mathrm{P}$ \\
\hline
\end{tabular}




\begin{tabular}{l|c|c|c|c|c|c|c|c} 
Annona emarginata (Schltdl.) H.Rainer & 13 & 1.3 & 10.0 & 2.2 & 0.32 & 0.6 & 4.0 & CL \\
\hline Solanum mauritianum Scop. & 5 & 0.5 & 10.0 & 2.2 & 0.29 & 0.5 & 3.2 & P \\
\hline Vernonanthura puberula (Less.) H.Rob. & 5 & 0.5 & 10.0 & 2.2 & 0.28 & 0.5 & 3.2 & P \\
\hline Myrcia splendens (Sw.) DC. & 5 & 0.5 & 10.0 & 2.2 & 0.14 & 0.2 & 2.9 & CL \\
\hline Ficus luschnathiana (Miq.) Miq. & 3 & 0.3 & 5.0 & 1.1 & 0.43 & 0.8 & 2.1 & CS \\
\hline Myrsine umbellata Mart. & 5 & 0.5 & 5.0 & 1.1 & 0.15 & 0.3 & 1.8 & P \\
\hline Ocotea puberula (Rich.) Nees & 3 & 0.3 & 5.0 & 1.1 & 0.18 & 0.3 & 1.7 & CL \\
\hline Styrax leprosus Hook. \& Arn. & 3 & 0.3 & 5.0 & 1.1 & 0.19 & 0.3 & 1.7 & CL \\
\hline Baccharis semiserrata DC. & 3 & 0.3 & 5.0 & 1.1 & 0.14 & 0.2 & 1.6 & P \\
\hline Critoniopsis quinqueflora (Less.) & 3 & 0.3 & 5.0 & 1.1 & 0.05 & 0.1 & 1.5 & P \\
H.Rob. & 999 & 100.0 & 460.0 & 100.0 & 57.28 & 100.0 & 300.0 & - \\
\hline Total & & & & &
\end{tabular}

Table 2. Relation of indicator species, sorted in decreasing order of importance value and recommended for enrichness plantings, at intermediate stage, in abandoned pastures in Serra do Itajai National Park, Santa Catarina state, Southern Brazil. IV = indicator value (significant for $P<0.05$ ).

\begin{tabular}{l|l|c|c}
\hline Family & Scientific name & IV (\%) & $\boldsymbol{P}$ \\
\hline Asteraceae & Vernonanthura discolor (Spreng.) H.Rob. & 83.4 & 0.001 \\
\hline Primulaceae & Myrsine coriacea (Sw.) R.Br. ex Roem. \& Schult. & 79.4 & 0.001 \\
\hline Asteraceae & Piptocarpha regnellii (Sch.Bip.) Baker & 72.2 & 0.007 \\
\hline Asteraceae & Piptocarpha angustifolia Dusén ex Malme & 34.6 & 0.017 \\
\hline Melastomataceae & Tibouchina sellowiana Cogn. & 30.0 & 0.028 \\
\hline Asteraceae & Piptocarpha axillaris (Less.) Baker & 29.5 & 0.047 \\
\hline Asteraceae & Baccharis dracunculifolia DC. & 25.0 & 0.048 \\
\hline Clethraceae & Clethra scabra Pers. & 25.0 & 0.041 \\
\hline
\end{tabular}

The recomposition of native species in degraded areas is a trivial activity. However, due to the great diversity of plant species, this function becomes delicate by several factors such as ecological, physiological and pedological specificities of each species or of the population as a whole. According to Meli et al. (2014), the adequacy of species is fundamental to the restoration projects, since these must be adapted to the conditions and resources available in the environment. Still, according to it, more research is needed to select appropriate species to meet the specific ecological requirements of the ecosystems. The lack of deepening in this theme was reported by Palma and Laurence (2015), analyzing 120 restoration works, noting that $30 \%$ of the experiments did not report the reason for the use of the selected species.

Another important factor in the restoration process and on the selection of species is the source and availability of seedlings and seeds. To Palma and Laurence (2015), the selection of species is significantly limited and potentially undermined by the availability of propagules and seedlings. The authors also highlight, among the fundamental characteristics, the phenotypic functions and genotypic plasticity in plant selection, and the rustification of seedlings in nurseries, prior to planting. 
Therefore, in order to better adapt to different conditions, it is suggested that the seeds and seedlings come from nearby the restoration area, avoiding risks associated to the introduction of germplasm, promoting the maintenance of genetic integrity and the recruitment of well adapted seedlings (Thomas et al., 2014). However, if the seed collection site is not set with local conditions, serious effects, such as seedling low survival or high mortality, may occur (Bresnan et al., 1994). The results of this work corroborate other researches trying to elucidate the premises that govern the successional process, by means of a phytosociological survey, characterizing the forest structure of fragments, and optimizing the identification of native species suitable for the restoration of degraded areas, in fragments of Montana Ombrophilous Dense Forest occurring in southern and southeastern Brazil.

Table 3. Relation of indicator species, sorted in decreasing order of importance value and recommended for enrichness plantings, at intermediate stage, in abandoned pastures in Serra do Itajai National Park, Santa Catarina state, Southern Brazil. IV = indicator value (significant for $P<0.05$ ).

\begin{tabular}{|c|c|c|}
\hline Species & Initial Stage (ind.ha $^{-1}$ ) & Intermediate Stage (ind.ha $^{-1}$ ) \\
\hline Annona emarginata (Schltdl.) H.Rainer & & 13 \\
\hline Baccharis dracunculifolia DC. & & 13 \\
\hline Baccharis semiserrata DC. & 8 & \\
\hline Clethra scabra Pers. & & 18 \\
\hline Critoniopsis quinqueflora (Less.) H.Rob. & & 3 \\
\hline Ficus luschnathiana (Miq.) Miq. & & 3 \\
\hline Ilex paraguariensis A.St.-Hil. & 3 & \\
\hline Myrcia splendens (Sw.) DC. & & 5 \\
\hline $\begin{array}{l}\text { Myrsine coriacea (Sw.) R.Br. ex Roem. \& } \\
\text { Schult. }\end{array}$ & 18 & 95 \\
\hline Myrsine umbellata Mart. & & 5 \\
\hline Ocotea puberula $($ Rich.) Nees & & 3 \\
\hline Piptocarpha angustifolia Dusén ex Malme & 13 & 17 \\
\hline Piptocarpha axillaris (Less.) Baker & 15 & 43 \\
\hline Piptocarpha regnellii (Sch.Bip.) Baker & 180 & 143 \\
\hline Solanum mauritianum Scop. & 3 & 2 \\
\hline Styrax leprosus Hook. \& Arn. & & 3 \\
\hline Tibouchina pilosa Cogn. & & 15 \\
\hline Tibouchina sellowiana Cogn. & & 28 \\
\hline Vernonanthura discolor (Spreng.) H.Rob. & 160 & 193 \\
\hline Vernonanthura puberula (Less.) H.Rob. & 15 & \\
\hline Zanthoxylum rhoifolium Lam. & 3 & \\
\hline Total & 418 & 602 \\
\hline
\end{tabular}

It is important to highlight that, in addition to the difficulties in distinguishing potential species to leverage restoration in Conservation Units, exist no less important factors such as bureaucratic and temporal obstacles. The liberation of any activity 
within a conservation unit (visitation, use of planting equipment, inputs to ensure plant development assistance, elimination of invasive alien species, etc.) must be properly licensed by the Brazilian environmental agencies, which does not necessarily occur in a rapid manner and consistent with the proposed restoration techniques. Conservation policies should encompass habitat variability, appropriately expand decision space, and support adaptation to local circumstances to increase ecological resilience in a rapidly changing world. A careful balance is needed between the development of conservation and management policies that assist in the conservation of endangered species, habitats and ecosystems, while maintaining and promoting the variability of natural systems (Hiers et al., 2016). According to the same authors, this distance between reality and policies is leading to wasted resources, misguided efforts and potential failures in efforts to conserve and restore nature, which will only become more prevalent in the face of ongoing climate change.

\section{Conclusion}

From the phytosociological survey of a degraded area inserted in the PSNI it was possible to characterize the forest structure of fragments of a Montana Ombrophilous Dense Forest, as well as the indication of potential species to assist in the restoration process by means of future plantings and enrichment.

The distinction among successional stages was verified by the evaluated parameters, in which each environment was characterized by one or more factors, providing relevant information on necessary ecological conditions and groups for the restoration of abandoned pasture areas in the PNSI region and nearby the phytoecological unit.

Current political and bureaucratic issues related to conservation management in Brazilian Conservation Units may be poorly correlated with the ecological complexity of natural systems and the necessary conservation practices and techniques, preventing the objectives and goals of ecological restoration of degraded environments in Brazil, or making them temporarily unfeasible.

Acknowledgements. To the National Economic and Social Development Bank (BNDES) and the Regional University of Blumenau (FURB), for the financial assistance provided to carry out this research, and to FURB specialist André Luís de Gasper, for the botanical identification of some species.

\section{REFERENCES}

[1] Albuquerque, J. A., Sangoi, L., Ender, M. (2001): Efeito da integração lavoura pecuária nas propriedades físicas do solo e características da cultura do milho. - Revista Brasileira de Ciência do Solo 25(3): 717-723.

[2] Alvares, C. A., Stape, J. L., Sentelhas, P. C., Moraes, G., Leonardo, J., Sparovek, G. (2013): Köppen's climate classification map for Brazil. - Meteorologische Zeitschrift 22(6): 711-728.

[3] Angiosperm Phylogeny Group IV (2016): The angiosperm phylogeny group III. An update of the Angiosperm Phylogeny Group classification for the orders and families of flowering plants: APG IV. - Botanical Journal of the Linnean Society 181(1): 1-20.

[4] Aumond. J. J., Müller, J. A., Refosco, J. C., Schorn, L. A., Vitorino, M. D., Fenilli, T. A. B. (2014): Projeto Restaurar, Diagnóstico geoambiental da localidade Faxinal do Bepe. descrição das unidades geoambientais. Projeto Restaurar, Blumenau. 
[5] Aumond. J. J., Loch, C., Comin, J. J. (2012): Abordagem sistêmica e o uso de modelos para recuperação de áreas degradadas. - Revista Árvore 36(6): 1099-1118.

[6] Blute, M. (2016): Density-dependent selection revisited: mechanisms linking explanantia and explananda. - Biological Theory 11(2):113-121.

[7] Brancalion, P. H. S., Gandolfi, S., Rodrigues, R. R. (2009): Incorporação do conceito da diversidade genética na restauração ecológica. 41-58 pp. - In: Rodrigues, R. R, Brancalion, P. H. S., Isernhagen, I. (eds.) Pacto pela restauração da Mata Atlântica. LERF/ESALQ: Instituto BioAtlântica, São Paulo.

[8] Bresnan, D. R., Rink, G., Diesel, K. E., Geyer, W. A. (1994): Black walnut provenance performance in seven 22-year-old plantations. - Silvae Genetica 43: 246-252.

[9] Colwell. R. K., Chao, A., Gotelli, N. J., Shang-Yi, L., Mao, C. X., Chazdon, R. L., Longino, J. T. (2011): Models and estimators linking individual-based and sample-based rarefaction. extrapolation and comparison of assemblages. - Plant Ecology 5(1): 3-21.

[10] Daronco, C., Melo, A. C. G., Durigan, G. (2013): Ecossistema em restauração versus ecossistema de referência: estudo de caso da comunidade vegetal de mata ciliar em região de Cerrado. Assis. SP. Brasil. - Hoehnea 40(3): 485-498.

[11] Dirzo, R., Raven, P. H. (2003): Global state of biodiversity and loss. - Annual Review of Environment and Resources 28(1): 137-167.

[12] Dufrene, M., Legendre, P. (1997): Species assemblages and indicator species: the need for a flexible assymetrical approach. - Ecological Monographs 67(3): 345-366.

[13] Eisenlohr, P.V. (2014): Persisting challenges in multiple models: a note on commonly unnoticed issues regarding collinearity and spatial structure of ecological data. - Brazilian Journal of Botany 37(3): 365-371.

[14] Finegan, B. (1996): Pattern and process neotropical secondary rain forests: the first 100 years of succession. - Tree 11(3): 119-124.

[15] Garcia, L. C., Hobbs, R. J., Ribeiro, D. B., Tamashiro, J. Y., Santos, F. A. M., Rodrigues, R. R. (2016): Restoration over time: is it possible to restore trees and non-trees in highdiversity forests? - Applied Vegetation Science 19: 655-666.

[16] Hallé, F. (2010): Arquitectura de los árboles. - Boletín de la Sociedad Argentina de Botánica 45(3-4): 405-418.

[17] Hiers, J. K., Jackson, S. T., Hobbs, R. J., Bernhardt, E. S., Valentine, L. (2016): The Precision Problem in Conservation and Restoration. - Trends in Ecology \& Evolution 31(11): 820-830.

[18] IBGE. (2012): Manual Técnico da Vegetação Brasileira. - Instituto Brasileiro de Geografia e Estatística, Rio de Janeiro.

[19] ICMBIO. (2009): Plano de Manejo do Parque Nacional da Serra do Itajaí. - Instituto Chico Mendes de Conservação da Biodiversidade, Brasília.

[20] Klein, R. M. (1980): Ecologia da flora e vegetação do Vale do Itajaí. - Sellowia 1(32): 165-389.

[21] Legendre, P., Legendre, L. (2012): Numerical ecology. - Elsevier, Amsterdam.

[22] Lingner, D. V., Schorn, L. A., Vibrans, A. C., Meyer, L., Sevegnani, L., Gasper, A. L., Sobral, M. G., Krüger, A., Klemz, G., Schmidt, R., Anastácio-Junior, C. (2013): Fitossociologia do componente arbóreo/arbustivo da Floresta Ombrófila Densa em Santa Catarina. - In: Vibrans, A. C., Sevegnani, L., Gasper, A. L., Lingner, D. V. (ed.). Inventário Florístico Florestal de Santa Catarina: Floresta Ombrófila Densa. Edifurb, Blumenau.

[23] Marcuzzo, S. B., Araújo, M. M, Rorato, D. G., Machado, J. (2014): Comparação entre áreas em restauração e área de referência no Rio Grande do Sul. Brasil. - Revista Árvore 38(6): 961-972.

[24] Martins. S. V. (2013): Recuperação de Áreas Degradadas: ações em áreas de preservação permanente. Voçorocas, taludes rodoviários e de mineração. UFV, Viçosa.

[25] McCune, B., Mefford, M. J. (2011): PC-ORD: Multivariate analysis of ecological data. Version 6. MjM Software Design, Gleneden Beach. 
[26] Meli, P., Martinez-Ramos, M., Rey-Benayas, J., Carabias, J. (2014): Combining ecological, social and technical criteria to select species for forest restoration. - Applied Vegetation Science 17: 744-753.

[27] Moro, M. F., Martins, F. R. (2011): Métodos de levantamento do componente arbóreoarbustivo. 174-212 pp. - In: Felfili, J. M. (ed.) Fitossociologia no Brasil: métodos e estudos de casos. UFV, Viçosa.

[28] Oliveira-Filho, A. T. (1994): Estudos ecológicos da vegetação como subsídios para programas de revegetação com espécies nativas: uma proposta metodológica. - Cerne 1(1): 64-72.

[29] Oliveira-Filho, A. T. (2015): Um sistema de classificação fisionômico-ecológico da vegetação neotropical: segunda aproximação. 452-473 pp. - In: Eisenlohr, P. V. (ed.) Fitossociologia no Brasil: métodos e estudos de casos. UFV, Viçosa.

[30] Palma, A. C., Laurence, S. G. W. (2015): A review of the use of direct seeding and seedling plantings in restoration: what dowe knowand where should we go? - Applied Vegetation Science 18: 561-568.

[31] Pandolfo, C., Braga, H. J., Silva, JR. V. P., Massignam, A. M., Pereira, E. S., Thomé, V. M. R., Valci, F. V. (2002): Atlas Climatológico do Estado de Santa Catarina. EPAGRI, Florianópolis.

[32] Rezende, C. L., Uezu, A., Scarano, F.R., Araujo, D. S. D. (2015): Atlantic Forest spontaneous regeneration at landscape scale. - Biodiversity and Conservation 24(9): 2255-2272.

[33] Reznick, D., Bryant, M. J., Bashey, F. (2002): r- and K-selection revisited: the role of population regulation in life-history evolution. - Ecology 83(6): 1509-1520.

[34] Rodrigues, R. R., Gandolfi, S. (2007): Restoration actions. 77-102pp. - In: Rodrigues, R. R., Martins, S. V. (eds.) Hight diversity forest restoration in degraded áreas: methods and projectin Brazil. New Science, New York.

[35] Rodrigues, R. R., Brancalion, P. H. S., Isernhagen, I. (2009): Pacto pela restauração da Mata Atlântica: referencial dos conceitos e ações de restauração florestal. Instituto BioAtlântica, São Paulo.

[36] Ruschel, A. R., Montovani, M., Reis, M. S., Nodari, R. O. (2009): Characterization and dynamics of two successional stages of secondary atlantic forest. - Revista Árvore 33(1): 101-115.

[37] Santos, H. G., Jacomini, P. K. T., Anjos, L.H.C., Oliveira, V.A., Oliveira, J.B., Coelho, M.R., Lumbreras, J.R., Cunha, T. J. F. (2013): Sistema brasileiro de classificação de solos. Embrapa Solos, Rio de Janeiro.

[38] Scarano, F. R., Ceotto, P. (2015): Brazilian Atlantic forest: impact. vulnerability. and adaptation to climate change. - Biodiversity and Conservation 24(9): 2319-2331.

[39] Schorn, L.A. (2005): Estrutura e dinâmica de estágios sucessionais de uma Floresta Ombrófila Densa em Blumenau, Santa Catarina. (192 pp.) Tese (Doutorado em Engenharia Florestal). Universidade Federal do Paraná. Curitiba.

[40] Schorn, L. A., Galvão, F. (2009): Dinâmica do estrato arbóreo em três estádios sucessionais de uma Floresta Ombrófila Densa em Blumenau, SC. - Cerne 15(2): 221235.

[41] Schorn, L.A., Maçaneiro, J. P. (2014): Projeto Restaurar: diagnóstico inicial da vegetação do Faxinal do Bepe. Projeto Restaurar, Blumenau.

[42] Sebben, A. M., (2002): Número de arvores matrizes e conceitos genéticos na coleta de sementes para reflorestamentos com espécies nativas. - Revista do Instituto Florestal 14: 115-132.

[43] Siminski, A. (2009): A floresta do futuro: conhecimento, valorização e perspectivas de uso das formações florestais secundárias no estado de Santa Catarina. (140 pp.) Tese (Doutorado em Recursos Genéticos Vegetais). Universidade Federal de Santa Catarina. Florianópolis. 
[44] Swaine, M. D., Whitmore, T. C. (1988): On the definition of ecological species groups in tropical rain forests. - Vegetatio 75(1):81-86.

[45] Thomas, E., Jalonen, R., Loo, J., Boshier, D., Gallo, L., Cavers, S., Bordács, S., Smith, P., Bozzano, M. (2014): Genetic considerations in ecosystem restoration using native tree Species. - Forest Ecology and Management 333: 66-75. 2014.

[46] Zanini, K. J., Bergamin, R. S., Machado, R. E., Pillar, V. D., Müller, S. C. (2014): Atlantic rain forest recovery: successional drivers of floristic and structural patterns of secondary forest in Southern Brazil. - Journal of Vegetation Science 25(4): 1056-1068. 